\title{
Analisis Kesesuaian Lahan Permukiman di Kecamatan Playen Kabupaten Gunungkidul menggunakan Pendekatan Analytical Hierarchy Process
}

\author{
Settlement Land Suitability Analysis in Playen Subdistrict Gunungkidul Regency using Analytic \\ Hierarchy Process
}

\author{
Hera Ratnawati 1, Prijono Nugroho Djojomartono ${ }^{2}$ \\ ${ }^{1}$ Alumni Departemen Teknik Geodesi FT-UGM, Indonesia \\ ${ }^{2}$ Staf Pengajar Departemen Teknik Geodesi FT-UGM, Indonesia
}

Penulis Korespondensi: Prijono Nugroho Djojomartono | Email: prinug@ugm.ac.id

Diterima (Received): 26/08/2020 Direvisi (Revised): 08/10/2020 Diterima untuk Publikasi (Accepted): 08/10/2020

\begin{abstract}
ABSTRAK
Peran Kecamatan Playen sebagai kecamatan dengan pertumbuhan ekonomi yang tinggi di Kabupaten Gunungkidul berpengaruh terhadap peningkatan kepadatan penduduk yang ada pada daerah tersebut setiap tahunnya. Kepadatan penduduk yang semakin meningkat dari tahun ke tahun menyebabkan kebutuhan akan ruang juga semakin meningkat, yang berdampak pada terjadinya alih fungsi lahan menjadi lahan permukiman. Penelitian ini bertujuan untuk melakukan analisis kesesuaian lahan permukiman di Kecamatan Playen Kabupaten Gunungkidul menggunakan metode Analytic Hierarchy Proces. Data yang digunakan dalam penelitian ini yaitu berupa data parameter AHP, Peta RDTR Kecamatan Playen dengan Peraturan Daerah Nomor 6 Tahun 2011 dan update data yang dilakukan pada tahun 2018, serta data administrasi berupa batas desa dan batas kecamatan Playen. Data parameter AHP terdiri dari kerawanan bencana, kemiringan lereng, penggunaan lahan, hidrogeologi, jarak terhadap jalan, jenis tanah dan curah hujan. Kesesuaian lahan permukiman diperoleh dengan metode Analytic Hierarchy Process. Proses yang dilakukan yaitu penghitungan AHP dengan menggunakan software Expert Choice 11, pembobotan terhadap masing-masing data parameter, untuk selanjutnya ditampalkan terhadap data administrasi Kecamatan Playen. Hasil akhir dalam penelitian ini yaitu tingkat kesesuaian lahan permukiman di Kecamatan Playen, yaitu S1 (sesuai), S2 (agak sesuai), S3 (kurang sesuai), N1 (tidak sesuai untuk saat ini), dan N2 (tidak sesuai permanen), dengan masing-masing luasan 1.771 ha dan proporsi 16,974\%; 3.865 ha dan proporsi 37,042 \%,; 2.647 ha dan proporsi 25,367 \%,; 1.893 ha dan proporsi 18,144 \%; dan 258 ha dan proporsi 2,472\%.
\end{abstract}

Kata Kunci: kesesuaian lahan permukiman, Analytical Hierarchy Process, RDTR, SIG

\section{ABSTRACT}

The role of Playen Subdistrict which is an area of high economic growth in Gunungkidul Regency, influences the increasing population density in the area each year. Increasing population density each year need space for living, which has an impact on the occurrence of land conversion into settlement land. This study aims to analyze the suitability of settlement land in the Playen Subdistrict Gunungkidul Regency using the Analytic Hierarchy Process method. The data used in this study are AHP parameter data, Playen Subdistrict RDTR Map with Regional Regulation Number 6 of 2011 and data updates conducted in 2018, and administration data in the form of village boundaries and Playen Subdistrict boundaries. AHP parameter data consists of disaster vulnerability, slope, land use, hydrogeology, distance to road, soil type and rainfall. Suitability of settlement land is obtained by the Analytic Hierarchy Process method. The process carried out is the calculation of AHP using Expert Choice 11 software, weighting of each parameter data, and then clamped to the Playen Subdistrict administrative data. The final result in this study is the suitability level of settlement land in Playen Subdistrict, there are S1 (suitable), S2 (moderately suitable), S3 (marginally suitable), N1 (currently not suitable), and N2 (permanently not suitable), with each area of 1,771 ha and the proportion of 16.974\%; 3,865 ha and the proportion of 37,042\%; 2,647 ha and the proportion of 25,367\%; 1,893 ha and the proportion of $18.144 \%$; and 258 ha and the proportion of $2,472 \%$.

Keywords: suitability of settlement land, Analytical Hierarchy Process, RDTR, GIS

(C) Author(s) 2020. This is an open access article under the Creative Commons Attribution-ShareAlike 4.0 International License (CC BY-SA 4.0). 


\section{Pendahuluan}

Tempat tinggal merupakan kebutuhan dasar manusia yang sangat penting. Seiring bertambahnya jumlah penduduk mengakibatkan peningkatan terhadap permintaan akan lahan, sementara ketersediaan lahan sangat terbatas. Lahan adalah suatu daerah di permukaan bumi dengan sifat-sifat tertentu yang meliputi biosfer, atmosfer, tanah, lapisan geologi, hidrologi, populasi tanaman dan hewan serta hasil kegiatan manusia masa lalu dan sekarang, sampai pada tingkat tertentu, dan sifatsifat tersebut mempunyai pengaruh yang berarti terhadap fungsi lahan oleh manusia pada masa sekarang dan masa yang akan datang (FAO 1976 dalam Notohadiprawiro 2006). UU No.1 Tahun 2011 tentang Perumahan dan Permukiman menyebutkan bahwa rumah adalah bangunan gedung yang berfungsi sebagai tempat tinggal yang layak huni, sarana pembinaan keluarga, cerminan harkat dan martabat penghuninya, serta aset bagi pemiliknya. Adanya ketimpangan antara permintaan lahan permukiman dan lahan yang tersedia berakibat pada alih fungsi lahan menjadi lahan permukiman. Salah satu upaya dalam perlindungan fungsi lahan yaitu dengan melakukan analisis kesesuaian lahan. Perencanaan penggunaan lahan sesuai dalam konteks penataan ruang wilayah maupun dalam upaya pengelolaan lahan secara spesifik perlu berdasar pada analisis sumber daya lahan (Baja, 2012). Analisis sumber daya lahan erat kaitannya terhadap kesesuaian lahan.

Menurut Baja (2012), kesesuaian lahan adalah tingkat kecocokan suatu jenis lahan untuk penggunaan tertentu yang dinilai berdasarkan analisis kualitas lahan sehubungan dengan persyaratan suatu jenis penggunaan tertentu, sehingga kualitas yang sesuai akan memberikan nilai lahan atau kelas yang tinggi terhadap jenis penggunaan tertentu. Kesesuaian lahan mempunyai berberapa tujuan yaitu mengidentifikasi, membuat perbandingan berbagai penggunaan lahan yang akan dikembangkan dan menentukan nilai potensi suatu lahan (Hardjowigeno, 2003; Al-Vatia \& Nugroho, 2019).

Pengelolaan dan perencanaan terhadap lahan menjadi sangat penting untuk memperhatikan kesesuaian lahan, selain mengacu pada rencana detail tata ruang yang ada pada wilayah tersebut. Lahan dengan karakteristik dan kualitas yang sesuai terhadap penggunaannya akan memiliki nilai yang tinggi, dibandingkan dengan lahan yang memiliki karakteristik dan kualitas yang kurang atau bahkan tidak sesuai terhadap penggunaannya. Seiring dengan semakin bertambahnya jumlah penduduk setiap tahunnya, menjadikan analisis kesesuaian lahan permukiman menjadi hal yang sangat mendesak untuk dilakukan. Penyediaan permukiman tersebut merupakan tanggung jawab pemerintah, swasta serta masyarakat, oleh karena itu pembangunan permukiman harus mendapat dukungan dari berbagai kebijakan yang menyangkut berbagai aspek serta harus disertai dengan pendekatan yang baik (Hilmansyah dan Rudiarto, 2015; Aditya dkk, 2020).

Kecamatan Playen merupakan salah satu pusat pertumbuhan ekonomi di Gunungkidul dengan pertumbuhan penduduk yang cukup tinggi (Ekoningsih, 2002). Menurut Harsono (1996), pertumbuhan ekonomi dan penduduk akan mempengaruhi semakin tingginya kebutuhan akan lahan terutama untuk kepentingan tempat tinggal sedangkan karakteristik lahan yang sesuai untuk permukiman terbatas. Pertumbuhan ekonomi yang tinggi tersebut berbanding lurus terhadap jumlah penduduk, sehingga kebutuhan akan lahan permukiman juga tinggi. Jumlah penduduk di Kecamatan Playen pada tahun 2014 adalah 57.112 orang. Tahun 2018 jumlah penduduk Kecamatan Playen bertambah menjadi 59.408 orang. Permintaan tempat tinggal di Kecamatan Playen tergolong tinggi (BPS Gunungkidul, 2018). Kecamatan Playen terdiri dari daerah dengan relief datar hingga berbukit, juga dengan jenis tanah yang beragam, sehingga tidak seluruh lahan di Kecamatan Playen tepat untuk digunakan sebagai lahan permukiman. Analisis kesesuaian lahan permukiman di Kecamatan Playen perlu dilakukan agar dapat bernilai ekonomis dan efektif bagi pengguna.

Penelitian ini bertujuan untuk melakukan analisis kesesuaian lahan permukiman di Kecamatan Playen Kabupaten Gunungkidul menggunakan metode Analytic Hierarchy Process (AHP). Analisis kesesuaian lahan permukiman di Kecamatan Playen dilakukan dengan melakukan analisis terhadap beberapa parameter yang menjadi kriteria dalam kesesuaian lahan permukiman, untuk selanjutnya dilakukan proses analisis. Sistem Informasi Geografis akan lebih memudahkan proses analisis (Setiawan, 2010; Astrisele \& Santosa, 2019). Proses SIG dapat membantu analisis data spasial terhadap parameter kesesuaian lahan permukiman. SIG dapat dipadukan dengan metode pengambilan keputusan dengan banyak kriteria (Mentari, 2013; Oksaping dkk, 2019; Wirandha \& Santosa, 2018). Metode pengambilan keputusan dengan banyak kriteria yang digunakan dalam analisis kesesuaian lahan permukiman di Kecamatan Playen yaitu metode Analytic Hierarchy Process. Metode AHP dapat menguraikan suatu masalah menjadi hierarki terstruktur, sehingga memudahkan dalam proses analisis. Oleh karena itu dalam penelitian ini dilakukan analisis kesesuaian lahan permukiman di Kecamatan Playen menggunakan teknologi SIG dan metode Analytic Hierarchy Process.

\section{Data dan Metodologi}

\subsection{Data dan Lokasi}

Penelitian ini dilakukan di Kecamatan Playen Kabupaten Gunungkidul, Provinsi Daerah Istimewa Yogyakarta. Data yang digunakan yaitu data sekunder, yang diperoleh dari Badan Perencanaan Pembangunan Daerah Kabupaten Gunungkidul. Data tersebut terdiri atas : 
Tabel 2.1 Tabel Data Penelitian

\begin{tabular}{clc}
\hline No & \multicolumn{1}{c}{ Data Penelitian } & \multicolumn{1}{c}{ Skala } \\
\hline $\mathbf{1}$ & $\begin{array}{l}\text { Peta Administrasi Kecamatan Playen } \\
\text { tahun 2018 }\end{array}$ & $1: 70.000$ \\
\hline $\mathbf{2}$ & $\begin{array}{l}\text { Peta Penggunaan Lahan Kabupaten } \\
\text { Gunungkidul tahun 2018 }\end{array}$ & $1: 200.000$ \\
\hline $\mathbf{3}$ & $\begin{array}{l}\text { Peta Curah Hujan Kabupaten } \\
\text { Gunungkidul tahun 2018 }\end{array}$ & $1: 200.000$ \\
\hline $\mathbf{4}$ & $\begin{array}{l}\text { Peta Jenis Tanah Kabupaten } \\
\text { Gunungkidul tahun 2018 }\end{array}$ & $1: 200.000$ \\
\hline $\mathbf{5}$ & $\begin{array}{l}\text { Peta Kemiringan Lereng Kecamatan } \\
\text { Playen tahun 2018 }\end{array}$ & $1: 70.000$ \\
\hline $\mathbf{6}$ & $\begin{array}{l}\text { Peta Hidrogeologi Kabupaten } \\
\text { Gunungkidul tahun 2018 }\end{array}$ & $1: 200.000$ \\
\hline $\mathbf{7}$ & $\begin{array}{l}\text { Peta Rencana Detail Tata Ruang } \\
\text { Kecamatan Playen tahun 2010 - 2030 } \\
\text { skala 1:70.000 }\end{array}$ & $1: 70.000$ \\
\hline
\end{tabular}

Data penelitian tersebut dalam format $m x d$ dan sistem proyeksi Universal Transverse Mercator (UTM) zona 49 South.

\subsection{Metodologi}

Metode yang digunakan dalam penelitian ini adalah metode Analytic Hierarchy Process. Metode AHP mendefinisikan masalah menjadi struktur hierarki hingga level terbawah yang berisi alternatif penyelesaian. Gambar 2.1 berikut merupakan diagram alir pelaksanaan dalam penelitian ini.

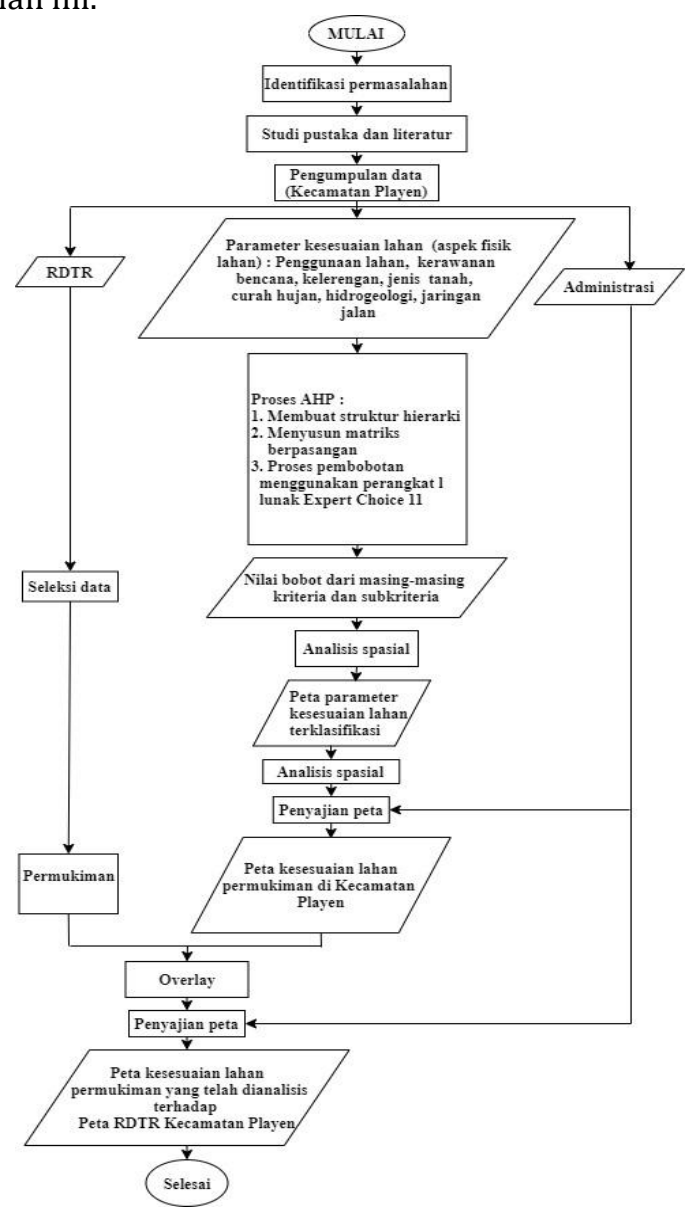

Gambar 2.1. Diagram pelaksanaan

Proses AHP dimulai dengan membuat struktur hierarki dari data parameter yang digunakan hingga sampai level terendah yaitu alternatif penyelesaian. Kriteria dan subkriteria parameter penelitian ini selanjutnya dimasukkan ke dalam matriks berpasangan untuk penentuan bobot kriteria dan subkriteria. Pembuatan matriks berpasangan didasarkan pada penilaian ahli dengan memberikan nilai yang mengacu pada skala perbandingan tingkat kepentingan, sehingga antar kriteria maupun antar subkriteria memiliki tingkat kepentingan yang berbeda. Tabel 2.2 merupakan skala perbandingan tingkat kepentingan.

Tabel 2.2. Skala perbandingan tingkat kepentingan Sumber : (Saaty, 1994)

\begin{tabular}{|c|c|c|c|}
\hline No & $\begin{array}{c}\text { Tingkat } \\
\text { Kepentingan }\end{array}$ & Definisi & Keterangan \\
\hline 1 & 1 & $\begin{array}{l}\text { Kedua } \\
\text { elemen sama } \\
\text { penting }\end{array}$ & $\begin{array}{l}\text { Dua elemen } \\
\text { mempunyai } \\
\text { pengaruh sama besar }\end{array}$ \\
\hline 2 & 3 & $\begin{array}{l}\text { Elemen yang } \\
\text { satu sedikit } \\
\text { lebih penting } \\
\text { daripada } \\
\text { yang lain }\end{array}$ & $\begin{array}{l}\text { Pengalaman dan } \\
\text { penilaian sedikit } \\
\text { menyokong satu } \\
\text { elemen }\end{array}$ \\
\hline 3 & 5 & $\begin{array}{l}\text { Elemen yang } \\
\text { satu lebih } \\
\text { penting dari } \\
\text { elemen yang } \\
\text { lain }\end{array}$ & $\begin{array}{l}\text { Pengalaman dan } \\
\text { penilaian dengan } \\
\text { kuat menyokong satu } \\
\text { elemen dibanding } \\
\text { elemen lainnya }\end{array}$ \\
\hline 4 & 7 & $\begin{array}{l}\text { Satu elemen } \\
\text { jelas lebih } \\
\text { penting dari } \\
\text { elemen } \\
\text { lainnya }\end{array}$ & $\begin{array}{l}\text { Satu elemen yang } \\
\text { kuat disokong dan } \\
\text { dominan terlibat } \\
\text { dalam kenyataan }\end{array}$ \\
\hline 5 & 9 & $\begin{array}{l}\text { Satu elemen } \\
\text { mutlak lebih } \\
\text { penting dari } \\
\text { elemen } \\
\text { lainnya }\end{array}$ & $\begin{array}{l}\text { Bukti yang } \\
\text { mendukung elemen } \\
\text { yang satu terhadap } \\
\text { elemen lain memiliki } \\
\text { tingkat penegasan } \\
\text { tertinggi yang } \\
\text { menguatkan }\end{array}$ \\
\hline 6 & $2,4,6,8$ & $\begin{array}{l}\text { Nilai-nilai di } \\
\text { antara dua } \\
\text { pertimbanga } \\
\text { n yang } \\
\text { berdekatan }\end{array}$ & $\begin{array}{l}\text { Nilai ini diberikan } \\
\text { bila ada dua } \\
\text { komponen di } \\
\text { antara dua } \\
\text { pilihan }\end{array}$ \\
\hline 7 & Kebalikan & $\alpha_{i j}=1 / \alpha_{j i}$ & $\begin{array}{l}\text { Jika untuk aktivitas } \\
\text { ke-i mendapat suatu } \\
\text { angka bila } \\
\text { dibandingkan } \\
\text { dengan aktivitas ke- } \\
\text { j maka j mempunyai } \\
\text { nilai kebalikannya } \\
\text { dibanding dengan i }\end{array}$ \\
\hline
\end{tabular}


Penghitungan AHP dilakukan dengan menggunakan software Expert Choice 11, sehingga dapat dhasilkan nilai bobot masing-masing kriteria dan subkriteria. Proses AHP menghasilkan rasio konsistensi (CR) yang berfungsi untuk menunjukkan tingkat konsistensi dari matriks perbandingan berpasangan yang telah dibuat dan untuk menunjukkan tingkat ketelitian dari nilai bobot yang dihasilkan. Berikut merupakan langkah dalam penghitungan rasio konsistensi (CR) :

a. Membuat matriks perbandingan berpasangan.

b. Melakukan perkalian kuadrat pada matriks perbandingan berpasangan.

c. Menjumlahkan secara horizontal hasil perkalian kuadrat matriks perbandingan berpasangan, dan menghitung jumlahnya.

d. Menghitung nilai eigen vector (nilai bobot)

Nilai eigen vector diperoleh dari melakukan pembagian pada masing-masing nilai hasil penjumlahan horizontal terhadap jumlah keseluruhannya.

e. Melakukan perhitungan untuk menentukan Vektor Jumlah Tertimbang (VJT)

Vektor Jumlah Tertimbang (VJT) diperoleh dengan melakukan perkalian pada matriks perbandingan berpasangan dan nilai bobot yang telah diperoleh.

f. Melakukan perhitungan untuk menentukan Vektor Konsistensi (VK)

Vektor Konsistensi (VK) diperoleh dengan melakukan pembagian pada masing-masing nilai Vektor Jumlah Tertimbang (VJT) terhadap nilai bobot (eigen vector).

g. Menghitung rata-rata dari Vektor Konsistensi $(\mathrm{VK}) / \lambda$

h. Menghitung Indeks Konsistensi (IK)

Indeks Konsistensi diperoleh dari perhitungan :

$\mathrm{IK}=(\lambda-\mathrm{n}) /(\mathrm{n}-1)$

Keterangan :

IK = Indeks Konsistensi

$\mathrm{n}=$ Jumlah Parameter

$\lambda=$ Vektor Konsistensi

i. Menghitung Rasio Konsistensi (CR)

$\mathrm{CR}=\mathrm{IK} / \mathrm{IR}$

Keterangan :

$\mathrm{CR}=$ Rasio Konsistensi

$\mathrm{IK}=$ Indeks Konsistens

$\mathrm{IR}=$ Indeks Rasio

Nilai bobot yang dihasilkan dari proses AHP digunakan dalam proses pembobotan yang dilakukan melalui software ArcGis 10.4.1. Langkah selanjutnya yaitu analisis spasial dan klasifikasi. Analisis spasial yang dilakukan yaitu raster calculator untuk menghasilkan kesesuaian lahan permukiman, sedangkan klasifikasi dilakukan dengan tools reclassify. Mengacu pada Hardjowigeno (2011), kesesuaian lahan permukiman dikelompokkan menjadi lima kelas. yaitu S1 (sesuai), S2 (agak sesuai), S3 (kurang sesuai), N1 (tidak sesuai untuk saat ini), dan N2 (tidak sesuai permanen). Langkah terakhir yaitu penyajian peta kesesuaian lahan permukiman di Kecamatan Playen, dan peta kesesuaian lahan permukiman di Kecamatan Playen yang telah disesuaikan terhadap RDTR Kecamatan Playen khususnya permukiman.

\section{Hasil dan Pembahasan}

3.1. Analisis AHP terhadap kriteria kesesuaian lahan permukiman di Kecamatan Playen

Nilai bobot pada kriteria menghasilkan rasio konsistensi (CR) 0,03 yang menunjukkan bahwa matriks berpasangan yang dibuat memiliki konsistensi yang baik, sehingga nilai bobot yang dihasilkan dapat digunakan untuk proses selanjutnya. Tabel 3.1 menunjukkan nilai bobot pada kriteria kesesuaian lahan permukiman.

Tabel 3.1. Nilai bobot kriteria kesesuaian lahan permukiman di Kecamatan Playen

\begin{tabular}{clc}
\hline No & \multicolumn{1}{c}{ Kriteria } & Bobot \\
\hline $\mathbf{1}$ & Kerawanan bencana & 0,401 \\
\hline $\mathbf{2}$ & Kemiringan lereng & 0,262 \\
\hline $\mathbf{3}$ & Penggunaan lahan & 0,131 \\
\hline $\mathbf{4}$ & Hidrogeologi & 0,085 \\
\hline $\mathbf{5}$ & Jarak terhadap jalan & 0,057 \\
\hline $\mathbf{6}$ & Jenis tanah & 0,038 \\
\hline $\mathbf{7}$ & Curah hujan & 0,027 \\
\hline & Total Bobot & 1 \\
\hline
\end{tabular}

3.2. Kerawanan bencana sebagai kriteria dalam analisis kesesuaian lahan permukiman di Kecamatan Playen

Berdasarkan pada proses AHP yang telah dilakukan, dihasilkan nilai rasio konsistensi (CR) sebesar 0,01 pada matriks perbandingan berpasangan antar subkriteria kerawanan bencana. Peta kerawanan bencana Kecamatan Playen dapat dilihat pada Gambar 3.1 berikut.

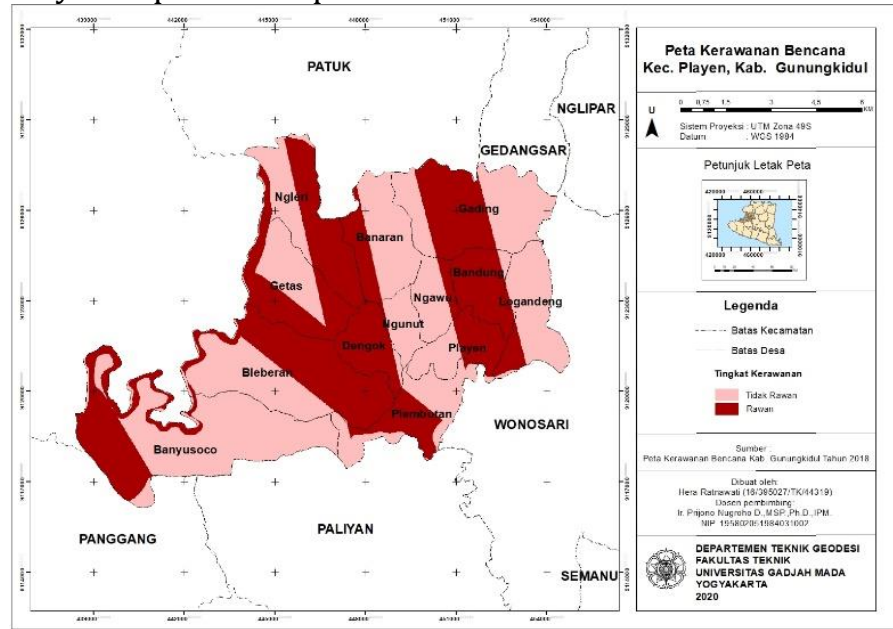

Gambar 3.1. Peta kerawanan bencana Kecamatan Playen sebagai kriteria dalam analisis kesesuaian lahan permukiman

Berdasar Peta kerawanan bencana Kecamatan Playen menunjukkan bahwa dalam kriteria kerawanan bencana 
diklasifikasikan menjadi tiga kelas subkriteria, yaitu tidak rawan, agak rawan dan rawan. Peta kerawanan bencana tersebut juga menunjukkan bahwa porsi untuk kawasan tidak rawan lebih besar dibandingkan kawasan yang masuk dalam kategori sebagai rawan bencana. Kawasan tidak rawan bencana memiliki bobot 0,669, dengan luasan 5.625 ha. Kawasan tidak rawan yaitu kawasan yang tidak masuk dalam wilayah rawan bencana. Kawasan agak rawan yaitu kawasan yang berada pada zona rawan bencana dan sebagian lain berada pada zona aman. Kawasan ini memiliki bobot 0,243. Kawasan rawan bencana yaitu kawasan yang seluruhnya berada pada zona rawan bencana. Kawasan ini memiliki bobot 0,088, dengan luasan 4.809 ha. Kawasan rawan bencana dalam penelitian ini dianalisis terhadap bencana tanah longsor dan gempa bumi.

\subsection{Kemiringan lereng sebagai kriteria dalam analisis}

kesesuaian lahan permukiman di Kecamatan Playen

Kriteria selanjutnya yaitu kemiringan lereng yang menjadi prioritas kedua. Berdasarkan proses AHP yang telah dilakukan, kemiringan lereng memiliki nilai bobot 0,262 . Selain itu juga dihasilkan nilai rasio konsistensi (CR) sebesar 0,01 pada matriks perbandingan berpasangan antar subkriteria kemiringan lereng. Persebaran wilayah di Kecamatan Playen ditinjau berdasarkan kriteria kemiringan lereng dapat dilihat pada Gambar 3.2 berikut.

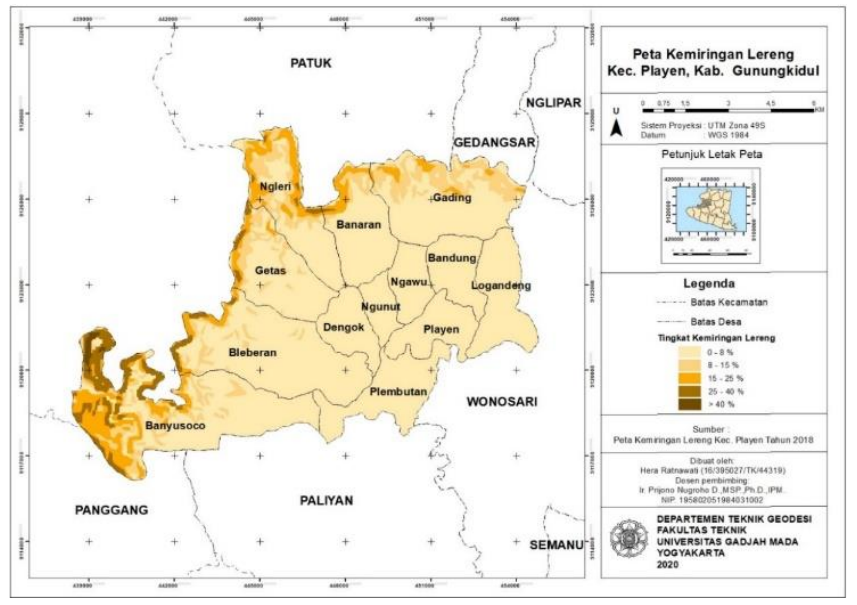

Gambar 3.2. Peta kemiringan lereng Kecamatan Playen sebagai kriteria dalam analisis kesesuaian lahan permukiman

Berdasar Peta kemiringan lereng Kecamatan Playen menunjukkan bahwa kemiringan lereng Kecamatan dikelompokkan menjadi lima subkriteria, yaitu 0 - $8 \%, 8$ $15 \%, 15-25 \%, 25-40 \%$, dan $>40 \%$. Peta kemiringan lereng tersebut juga menunjukkan bahwa wilayah Kecamatan Playen didominasi oleh daerah dengan tingkat kemiringan lereng $0-15 \%$, hanya sebagian kecil wilayah yang merupakan daerah dengan tingkat kemiringan lereng terjal. Kelas kemiringan lereng prioritas pertama yaitu kemiringan $0-8 \%$ yang memiliki bobot 0,450 . Di
Kecamatan Playen, tingkat kemiringan lereng ini memiliki luas sebesar 8068 ha.

Kelas kemiringan lereng prioritas kedua yaitu 8 - $15 \%$ memiliki bobot 0,297. Di Kecamatan Playen, tingkat kemiringan lereng ini memiliki luas sebesar 1159 ha. Tingkat kemiringan lereng pada prioritas ketiga yaitu 15 $25 \%$ dan memiliki bobot 0,151. Kemiringan lereng ini termasuk dalam wilayah bergelombang hingga berbukit.

Wilayah dengan kemiringan lereng ini masih dapat digunakan sebagai permukiman. Terdapat 795 ha wilayah di Kecamatan Playen dengan tingkat kemiringan lereng ini. Tingkat kemiringan lereng skala prioritas keempat yaitu $25-40 \%$ dan memiliki bobot 0,065. Kemiringan lereng ini mencakup daerah berbukit hingga pegunungan. Wilayah dengan kemiringan lereng ini tidak direkomendasikan sebagai permukiman. Terdapat 383 ha wilayah di Kecamatan Playen yang memiliki tingkat kemiringan lereng 25 - $40 \%$. Skala prioritas kelima yaitu kemiringan lereng $>40 \%$. Kemiringan lereng ini memiliki bobot 0,037. Daerah dengan kemiringan lereng $>40 \%$ yaitu berupa pegunungan curam. Daerah ini memiliki resiko yang tinggi jika digunakan sebagai permukiman. Terdapat 29 ha wilayah di Kecamatan Playen yang memiliki tingkat kemiringan lereng $>40 \%$.

3.4. Penggunaan lahan sebagai kriteria dalam analisis kesesuaian lahan permukiman di Kecamatan Playen

Kriteria skala prioritas ketiga yaitu penggunaan lahan. Berdasarkan pada proses AHP yang telah dilakukan, kriteria ini memiliki bobot 0,131. Selain itu juga dihasilkan nilai rasio konsistensi (CR) sebesar 0,01 pada matriks perbandingan berpasangan antar subkriteria penggunaan lahan. Persebaran kesesuaian penggunaan lahan untuk permukiman di Kecamatan Playen dapat dilihat pada Gambar 3.3 berikut.

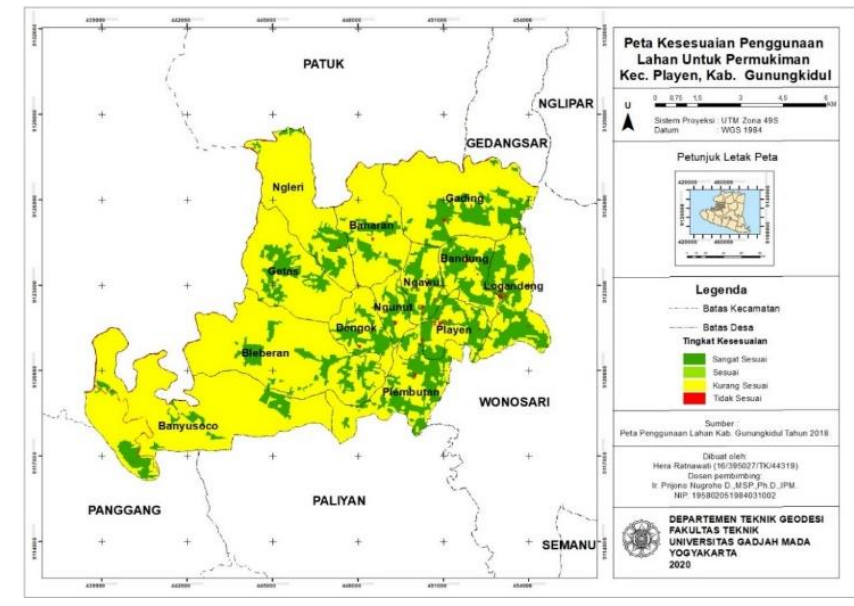

Gambar 3.3. Peta kesesuaian penggunaan lahan untuk permukiman Kecamatan Playen sebagai kriteria dalam analisis kesesuaian lahan permukiman

Berdasarkan Peta kesesuaian penggunaan lahan untuk permukiman Kecamatan Playen menunjukkan bahwa kesesuaian penggunaan lahan untuk permukiman 
Kecamatan Playen diklasifikasikan menjadi empat kelas. Kriteria sangat sesuai sebagai prioritas pertama, memiliki bobot 0,520. Subkriteria ini terdiri dari wilayah yang hanya berisi permukiman saja. Oleh karena itu, wilayah yang termasuk dalam permukiman mendapatkan nilai bobot tertinggi dalam subkriteria ini. Terdapat 2330 ha lahan sangat sesuai di Kecamatan Playen. Subkriteria prioritas kedua yaitu sesuai, memiliki bobot 0,337 . Kategori kelas sesuai yaitu terdiri dari lahan campuran permukiman. Wilayah dengan subkriteria sangat sesuai dan sesuai sangat cocok digunakan sebagai permukiman. Subkriteria ini tidak terdapat di Kecamatan Playen. Subkriteria ketiga yaitu kurang sesuai, yang memiliki bobot 0,094 . Penggunaan lahan yang kurang sesuai yaitu mencakup perdagangan jasa, perkantoran, terminal, tegalan, kebun dan gedung. Wilayah dengan penggunaan tersebut tidak direkomendasikan sebagai permukiman. Terdapat 8.011 ha wilayah di Kecamatan Playen yang termasuk dalam penggunaan lahan kurang sesuai. Subkriteria keempat yaitu tidak sesuai,yang memiliki bobot 0,048 dan seluas 93 ha. Kategori kelas tidak sesuai mencakup makam, olahraga, konservasi, kesehatan, rekreasi, kawasan militer dan air. Wilayah dengan penggunaan lahan tersebut sangat tidak direkomendasikan untuk digunakan sebagai permukiman.

\subsection{Hidrogeologi sebagai kriteria dalam analisis} kesesuaian lahan permukiman di Kecamatan Playen

Hidrogeologi berada pada tingkat skala prioritas keempat pada tingkat kepentingan kriteria kesesuaian lahan permukiman. Berdasarkan pada proses AHP yang telah dilakukan, kriteria ini memiliki bobot 0,085 . Selain itu, juga dihasilkan nilai rasio konsistensi (CR) sebesar 0,01 pada matriks perbandingan berpasangan antar subkriteria hidrogeologi. Peta hidrogeologi Kecamatan Playen ditunjukkan pada Gambar 3.4 berikut.

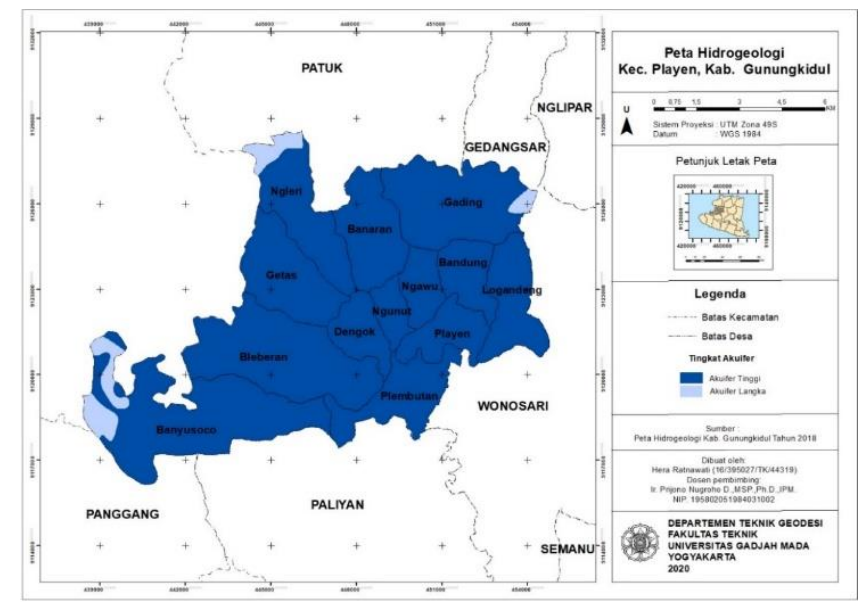

Gambar 3.4. Peta hidrogeologi Kecamatan Playen sebagai kriteria dalam analisis kesesuaian lahan permukiman

Subkriteria dalam hidrogeologi dibagi menjadi empat kelas, yaitu akuifer langka, akuifer kecil, akuifer sedang dan akuifer tinggi. Gambar 5 menunjukkan bahwa hanya terdapat dua kelas subkriteria di Kecamatan Playen, yaitu akuifer langka dan akuifer tinggi. Gambar 5 juga menunjukkan bahwa wilayah di Kecamatan Playen didominasi oleh daerah yang memiliki akuifer tinggi. Subkriteria prioritas pertama yaitu akuifer tinggi, memiliki bobot 0,517. Daerah dengan akuifer tinggi ini memiliki luasan sebesar 9.995 ha. Hal tersebut menunjukkan bahwa sebagian besar wilayah di Kecamatan Playen masih memadai dalam hal ketersediaan air. Subkriteria prioritas kedua yaitu hidrogeologi dengan akuifer sedang, memiliki bobot 0,334. Subkriteria prioritas ketiga yaitu hidrogeologi dengan akuifer kecil, memiliki bobot 0,096. Hidrogeologi dengan akuifer sedang dan kecil tidak terdapat di Kecamatan Playen. Subkriteria prioritas terakhir yaitu akuifer langka, memiliki bobot 0,053 . Terdapat 429 ha wilayah di Kecamatan Playen yang memiliki hidrogeologi dengan akuifer langka.

3.6. Jarak terhadap jalan sebagai kriteria dalam analisis kesesuaian lahan permukiman di Kecamatan Playen

Kriteria dengan skala prioritas kelima yaitu jarak terhadap jalan. Kriteria ini memiliki bobot 0,057. Selain itu, juga dihasilkan nilai rasio konsistensi (CR) sebesar 0,01 pada matriks perbandingan berpasangan antar subkriteria jarak terhadap jalan. Peta jarak lokasi untuk permukiman terhadap jalan di Kecamatan Playen dapat dilihat pada Gambar 3.5 berikut.

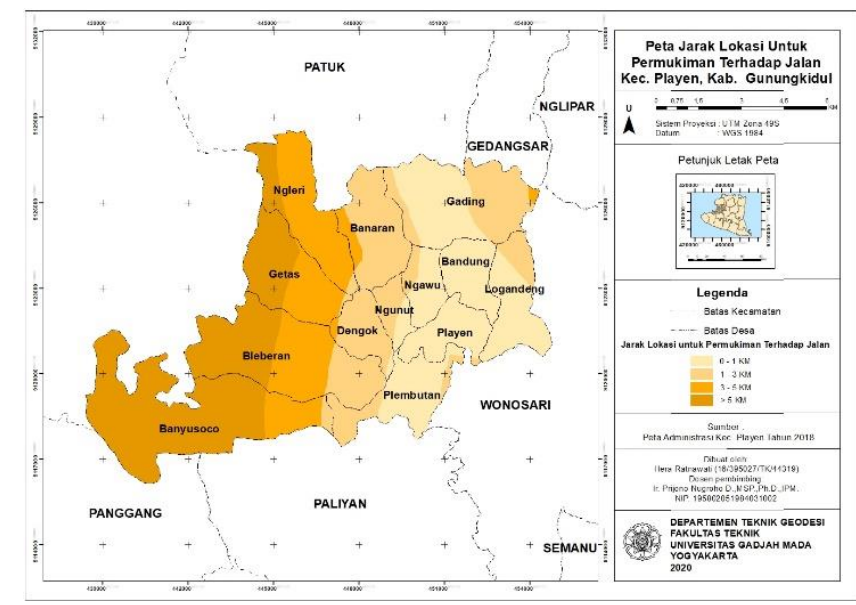

Gambar 3.5. Peta jarak terhadap jalan Kecamatan Playen sebagai kriteria dalam analisis kesesuaian lahan permukiman

Berdasarkan Peta jarak terhadap jalan Kecamatan Playen sebagai kriteria dalam analisis kesesuaian lahan permukiman di atas menunjukkan bahwa subkriteria jarak terhadap jalan dibagi menjadi empat kelas, yaitu 0 - $1 \mathrm{KM}$, $1-3 \mathrm{KM}, 3-5 \mathrm{KM}$, dan $>5 \mathrm{KM}$. Kelas $0-1 \mathrm{KM}$ memiliki bobot 0,520 . Lokasi yang berada dalam kelas ini memiliki aksesibilitas yang sangat baik sehingga memudahkan pengguna untuk menuju lokasi tersebut. Adanya faktor kedekatan terhadap jalan ini menjadi salah satu faktor 
yang penting dalam kesesuaian lahan permukiman. Terdapat 2.832 ha wilayah di Kecamatan Playen yang termasuk dalam subkriteria ini.

Subkriteria prioritas kedua yaitu kelas 1 - 3 KM jarak terhadap jalan. Kelas ini memiliki bobot 0,337. Lokasi yang termasuk dalam kelas ini juga dapat direkomendasikan untuk permukiman, ditinjau dari segi jarak terhadap jalan. Terdapat 2.564 ha wilayah di Kecamatan Playen yang termasuk dalam subkriteria prioritas kedua. Skala prioritas ketiga yaitu kelas 3 - 5 KM memiliki bobot 0,094. Lokasi yang berada pada subkriteria ini masih dapat direkomendasikan sebagai permukiman. Jarak 3 - 5 KM terhadap jalan masih memungkinkan untuk dijangkau dengan mudah.

Wilayah di Kecamatan Playen yang termasuk dalam kelas ini seluas 1.968 ha. Kelas dengan skala prioritas terakhir yaitu jarak terhadap jalan $>5 \mathrm{KM}$. Kelas ini memiliki bobot 0,048 . Lokasi yang berada pada subkriteria ini tidak direkomendasikan sebagai permukiman. Hal tersebut dikarenakan jarak $>5 \quad \mathrm{KM}$ terhadap jalan menunjukkan bahwa aksesibilas pada lokasi tersebut cukup sulit untuk dijangkau. Terdapat 3.070 ha wilayah di Kecamatan Playen yang termasuk dalam subkriteria ini.

3.7. Jenis tanah sebagai kriteria dalam analisis kesesuaian lahan permukiman di Kecamatan Playen

Kriteria dengan skala prioritas keenam yaitu jenis tanah. Berdasarkan pada proses AHP yang telah dilakukan, kriteria ini memiliki bobot 0,038. Selain itu, juga dihasilkan nilai rasio konsistensi (CR) sebesar 0,01 pada matriks perbandingan berpasangan antar subkriteria jenis tanah. Peta jenis tanah Kecamatan Playen dapat dilihat pada Gambar 3.6 berikut.

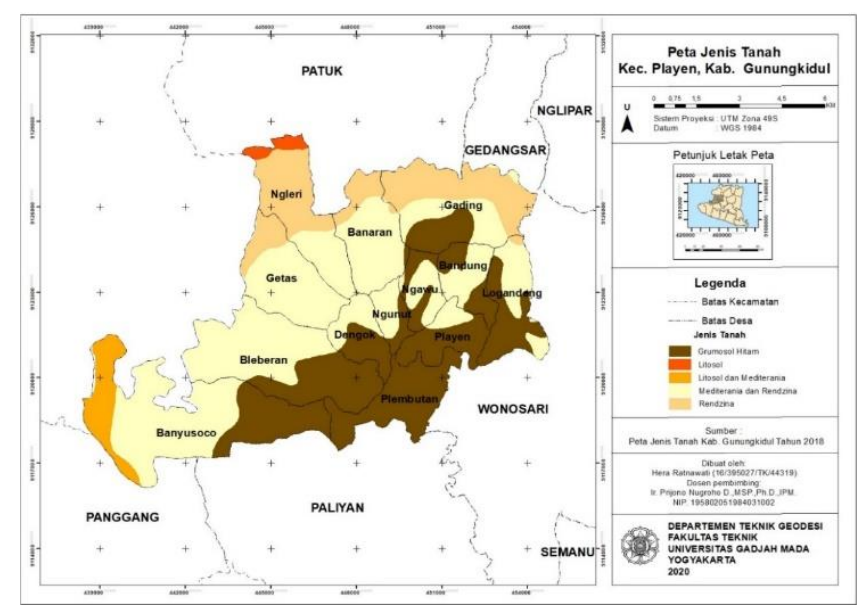

Gambar 3.6. Peta jenis tanah Kecamatan Playen sebagai

kriteria dalam analisis kesesuaian lahan permukiman

Gambar 7 Peta jenis tanah Kecamatan Playen menunjukkan bahwa jenis tanah yang berada di Kecamatan Playen yaitu litosol, rendzina, grumosol hitam, mediterania dan grumosol hitam, serta mediterania dan rendzina. Jenis tanah litosol dan rendzina termasuk dalam kategori sangat peka terhadap erosi, sedangkan jenis tanah grumosol hitam, campuran mediterania dan grumosol hitam, serta campuran mediterania dan rendzina termasuk dalam kategori peka terhadap erosi. Peta jenis tanah tersebut juga menunjukkan bahwa wilayah Kecamatan Playen didominasi oleh jenis tanah yang peka terhadap erosi.

Subkriteria prioritas pertama yaitu kelas jenis tanah tidak peka, memiliki bobot 0,437 . Jenis tanah ini tidak terdapat di Kecamatan Playen. Jenis tanah yang masuk dalam kelas tidak peka yaitu alluivial, gleiplanosol, hidomorf kelabu, dan laterita. Jenis tanah dalam skala prioritas kedua yaitu tanah kurang peka. Jenis tanah ini memiliki bobot 0,282 . Tanah yang termasuk dalam kelas kurang peka yaitu latosol. Latosol merupakan tanah dengan kedalaman solum $>2 \mathrm{~m}$, berwarna merah kecoklatan sampai kuning, bertekstur liat, berstruktur remah atau gempal, konsistensi gembur di bagian atas dan teguh dibagian bawah. Jenis tanah skala prioritas ketiga yaitu agak peka. Jenis tanah ini memiliki bobot 0,148 . Tanah yang termasuk dalam kategori ini yaitu brown forest soil, noncalsic brown, dan mediteran. Jenis tanah pada skala prioritas keempat yaitu peka. Jenis tanah ini memiliki bobot 0,082 .

Tanah yang termasuk dalam kategori peka yaitu andosol, laterit, grumosol, podsol, dan podsolik. Di Kecamatan Playen terdapat tanah grumosol yang masuk dalam kategori ini. Grumosol merupakan tanah yang berkembang dari sedimen laut yang telah terangkat atau bahan yang dipengaruhi oleh formasi kapur. Terdapat 8.802 ha wilayah di Kecamatan Playen yang memiliki jenis tanah dengan kelas ini. Jenis tanah pada skala prioritas kelima yaitu sangat peka. Jenis tanah ini memiliki bobot 0,050 . Beberapa jenis tanah yang termasuk dalam kategori ini yaitu regosol, organosol, renzina, dan litosol. Di Kecamatan Playen terdapat jenis tanah renzina dan litosol. Jenis tanah ini terdapat di 1.632 ha wilayah di Kecamatan Playen.

3.8. Curah hujan sebagai kriteria dalam analisis kesesuaian lahan permukiman di Kecamatan Playen

Berdasarkan pada proses AHP yang telah dilakukan, kriteria curah hujan memiliki bobot 0,027 . Selain itu, juga dihasilkan nilai rasio konsistensi (CR) sebesar 0,01 pada matriks perbandingan berpasangan antar subkriteria curah hujan. Curah hujan Kecamatan Playen hanya terdiri dari subkriteria prioritas pertama, yaitu curah hujan dengan kelas 0-13.6 mm/hari. Curah hujan dengan kelas 0 - 13,6 mm/hari memiliki bobot 0,013. Hal tersebut dapat menjadi penyeimbang jenis tanah yang peka terhadap erosi sehingga dapat meningkatkan daya dukung lahan yang ada di Kecamatan Playen. Selain itu, curah hujan pada kelas ini juga berdampak positif terhadap kegiatan manusia, karena dengan adanya curah hujan yang tidak tinggi, maka hal tersebut dapat memperlancar kegiatan manusia dan kegiatan transportasi di wilayah tersebut. 
Curah hujan ini merupakan curah hujan yang paling sesuai untuk permukiman. Curah hujan pada prioritas kedua yaitu kelas 13,6 - 20,7 mm/hari. Curah hujan pada kelas ini memiliki bobot 0,008 . Subkriteria curah hujan pada kelas ini dikategorikan sesuai untuk permukiman. Curah hujan pada prioritas ketiga yaitu 20,7 - 20,7 $\mathrm{mm} /$ hari. Curah hujan ini memiliki bobot 0,005 dan dikategorikan agak sesuai, karena curah hujan tersebut sudah cukup tinggi untuk permukiman. Curah hujan pada prioritas keempat yaitu 27,7 - 34,8 mm/hari, memiliki bobot 0,003 . Curah hujan pada subkriteria ini adalah curah hujan yang tinggi dan tidak direkomendasikan untuk daerah permukiman.

Curah hujan skala prioritas terakhir yaitu dengan kelas $>34,8 \mathrm{~mm} /$ hari. Curah hujan ini memiliki bobot 0,001 . Tingginya curah hujan tersebut sangat tidak direkomendasikan untuk permukiman, dikarenakan curah hujan yang terlalu tinggi. Curah hujan yang terlalu tinggi ini dapat memperburuk daya dukung lahan sehingga dikhawatirkan dapat mendorong terjadinya erosi pada tanah.

3.9. Kesesuaian lahan permukiman di Kecamatan Playen berdasarkan metode AHP dan AHP yang telah disesuakan terhadap RDTR

Kesesuaian lahan permukiman di Kecamatan Playen dihasilkan dari proses Analytic Hierarchy Process dengan menggunakan parameter yang berdasarkan pada SNI 031733-2004 tentang perencanaan kawasan perumahan dan permukiman, sehingga menghasilkan lima kelas klasifikasi kesesuaian, yaitu sesuai, agak sesuai, kurang sesuai, tidak sesuai untuk saat ini, dan tidak sesuai permanen. Berikut merupakan peta kesesuaian lahan permukiman di Kecamatan Playen berdasarkan metode AHP, dan peta kesesuaian lahan permukiman di Kecamatan Playen berdasarkanmetode AHP yang telah dilakukan overlay terhadap RDTR Kecamatan Playen khususnya permukiman.

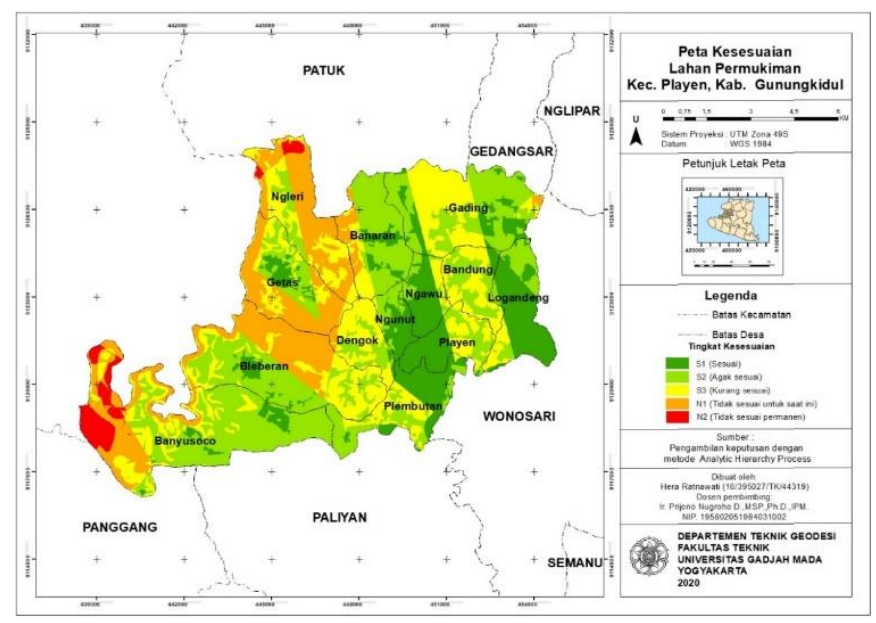

Gambar 3.7. Peta kesesuaian lahan permukiman Kecamatan Playen berdasarkan metode AHP

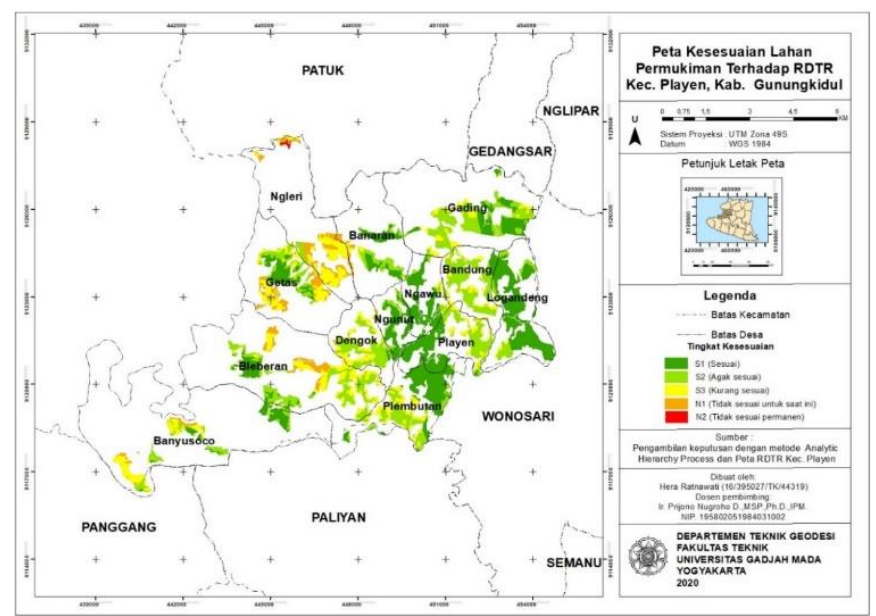

Gambar 3.8. Peta kesesuaian lahan permukiman Kecamatan Playen berdasarkan metode AHP dan RDTR

Gambar 3.7 dan Gambar 3.8 di atas menunjukkan bahwa kesesuaian lahan permukiman di Kecamatan Playen berdasarkan metode AHP dan metode AHP yang telah disesuaikan terhadap RDTR Kecamatan Playen menghasilkan luas yang berbeda. Lahan S1 (sesuai) berdasarkan metode AHP yaitu 1.771 ha, sedangkan berdasarkan metode AHP yang telah disesuaikan terhadap RDTR Kecamatan Playen yaitu 1.072 ha dengan persentase $36,205 \%$ dari keseluruhan luas rencana permukiman yang ada di RDTR Kecamatan Playen. Selanjutnya yaitu lahan S2 (agak sesuai) menyebar seluas 3.865 ha di Kecamatan Playen, adapun yang termasuk ke dalam lahan yang direncanakan untuk permukiman yaitu seluas 1.043 ha dengan persentase 35,205 \% dari keseluruhan lahan yang direncanakan untuk permukiman di Kecamatan Playen. Lahan pada prioritas ketiga yaitu S3 (kurang sesuai) tersebar seluas 2.647 ha di Kecamatan Playen, adapun yang direncanakan untuk permukiman yaitu seluas 658 ha dengan persentase 22,211 \% dari keseluruhan rencana permukiman di Kecamatan Playen.

Kesesuaian pada prioritas keempat yaitu lahan N1 (tidak sesuai untuk saat ini), tersebar seluas 1.893 ha di Kecamatan Playen, dan yang direncanakan untuk permukiman yaitu seluas 184 ha dengan persentase 6,211 \% dari keseluruhan lahan yang direncanakan untuk permukiman di Kecamatan Playen. Lahan pada kelas ini tidak direkomendasikan untuk dimanfaatkan sebagai permukiman. Hal tersebut dikarenakan terdapat beberapa parameter yang dikhawatirkan dapat membahayakan bagi pengguna lahan, salah satunya yaitu adanya faktor kerawanan bencana yang ada pada lahan ini. Selanjutnya yaitu lahan N2 (tidak sesuai permanen), tersebar seluas 258 ha di Kecamatan Playen, adapun yang direncanakan untuk permukiman yaitu seluas 5 ha dengan persentase $0,157 \%$ dari keseluruhan lahan yang direncanakan untuk permukiman di Kecamatan Playen. Lahan pada kelas ini tidak direkomendasikan untuk permukiman karena dikhawatirkan akan merugikan bagi pengguna lahan. Tabel 3.2 merupakan tabel persebaran luas kesesuaian 
lahan permukiman di Kecamatan Playen berdasarkan metode AHP dan metode AHP yang telah disesuaikan terhadap RDTR.

Tabel 3.2 Persebaran luas kesuaian lahan permukiman berdasarkan metode AHP dan metode AHP + RDTR

\begin{tabular}{cccccc}
\hline & \multirow{2}{*}{$\begin{array}{c}\text { Kelas } \\
\text { Kesesuaian }\end{array}$} & \multicolumn{2}{c}{ Metode AHP } & \multicolumn{2}{c}{$\begin{array}{c}\text { Metode AHP + } \\
\text { RDTR }\end{array}$} \\
\cline { 3 - 6 } & & Luas (ha) & $\begin{array}{c}\text { Persentase } \\
(\%)\end{array}$ & Luas (ha) $\begin{array}{c}\text { Persentase } \\
(\%)\end{array}$ \\
\hline $\mathbf{1}$ & S1 & 1.771 & 16,974 & 1.071 & 36,205 \\
\hline $\mathbf{2}$ & S2 & 3.865 & 37,042 & 1.043 & 35,205 \\
\hline $\mathbf{3}$ & S3 & 2.647 & 25,367 & 658 & 22,211 \\
\hline $\mathbf{4}$ & N1 & 1.893 & 18,144 & 184 & 6,221 \\
\hline $\mathbf{5}$ & N2 & 258 & 2,472 & 5 & 0,157 \\
\hline & Total & 10.434 & 100 & 2.962 & 100 \\
\hline
\end{tabular}

\section{Kesimpulan}

Kesesuaian lahan permukiman di Kecamatan Playen berdasarkan metode AHP menghasilkan lima kelas kesesuaian lahan. Lima kelas kesesuaian tersebut yaitu S1 (sesuai) dengan luasan 1.771 hektar dan proporsi $16,974 \%$, gfggf S2 (agak sesuai) dengan luasan 3.865 hektar dan proporsi 37,042 \%, S3 (kurang sesuai) dengan luasan 2.647 hektar dan proporsi 25,367 \%, N1 (tidak sesuai untuk saat ini) dengan luasan 1.893 hektar dan proporsi $18,144 \%$, dan N2 (tidak sesuai permanen) dengan luasan 258 hektar dan proporsi 2,472 \%. Rencana Detail Tata Ruang khususnya rencana permukiman di Kecamatan Playen memiliki kesesuaian S1 (sesuai), S2 (agak sesuai), S3 (kurang sesuai) sebesar 93,622\% dan $6,378 \%$ dengan kategori tidak sesuai.

\section{Pernyataan Konflik Kepentingan}

Penulis menyatakan tidak ada konflik kepentingan dalam artikel ini (The authors declare no competing interest).

\section{Referensi}

Aditya, T., Maria-Unger, E., Berg, C., Bennett, R., Saers, P., Syahid, H. L., Erwan, D., Wits, T., Widjajanti, N., Santosa, P. B., Atunggal, D., Hanafi, I., dan Sutejo, D. (2020). Participatory Land Administration in Indonesia: Quality and Usability Assessment. Land. 9(3), 79. https://doi.org/10.3390/land9030079

Al-Vatia, T. V., \& Nugroho, P. D. (2019). Analysis of the Effect of Land Use Planning and Land Value in Gamping Subdistrict, Sleman, D.I Yogyakarta from 2013 to 2018. JGISE: Journal of Geospatial Information Science and Engineering. Vol. 2 No. 2, pp. 245 - 254. https://jurnal.ugm.ac.id/jgise/article/view/51076
Anonim. (2018). Rata-Rata Laju Pertumbuhan Penduduk Pertahun. Gunungkidulkab.bps.go.id (diakses pada 19 Juni 2020)

Astrisele, A. \& Santosa, P. B. (2019). Estimating Land Value Change Post Land Consolidation of Gadingsari Village, Bantul Regency, Special Region of Yogyakarta, Indonesia. JGISE: Journal of Geospatial Information Science and $\begin{array}{lllll}\text { Engineering. } & \text { Vol. } & 2 & \text { No. }\end{array}$ https://doi.org/10.22146/jgise.51309

Baja, S. (2012). Perencanaan Tata Guna Lahan dalam Pengembangan Wilayah. Yogyakarta : CV Andi Offset.Harjowigeno, S. (2003). Ilmu Tanah. Jakarta : Akademika Presindo.

Ekoningsih, Y. (2002). Evaluasi Penetapan Kecamatan sebagai Pusat Pertumbuhan Ekonomi di Kabupaten Gunungkidul. Tesis. Yogyakarta : Universitas Gadjah Mada

Hardjowigeno, S., \& Widiatmaka. (2011). Evaluasi Kesesuaian Lahan dan Perencanaan Tataguna Tanah. Yogyakarta : Gadjah Mada University Press.

Harsono, S. (1996). Kebutuhan Tanah dan Managemen Pengelolaannya dalam Pembangunan Nasional, Makalah, Seminar Nasional Peringatan 26 Tahun Keluarga Mahasiswa Teknik Geodesi. Yogyakarta. UGM

Hilmansyah, H. DKK. (2015). Kajian Perkembangan Dan Kesesuaian Lahan Permukiman Eksisting DI Kecamatan Indramayu. Jurnal Teknik PWK, Volume 4 Nomor 1.

Mentari, F. (2016). Sistem Informasi Penentuan Lokasi TPA Sampah Menggunakan Metode AHP Studi Kasus : Dinas Kebersihan dan Pertamanan Kota Malang. Jurnal Teknologi Informatika.

Oksaping, A. F., Djurdjani, dan Nugroho, P. (2019). Land Valuation with Analytical Hierarchy Process and Regression Method in Grogol Sub-District, Sukoharjo District. JGISE: Journal of Geospatial Information Science and Engineering. Vol. 2 No. 1 https://doi.org/10.22146/igise.40845

Peraturan Kepala Badan Nasional Penanggulangan Bencana Nomor 02 Tahun 2012 Tentang Pedoman Umum Pengkajian Risiko Bencana.

Saaty, T. L. (1993). Pengambilan Keputusan Bagi Para Pemimpin, Proses Hirarki Analitik untuk Pengambilan Keputusan dalam Situasi yang Kompleks. Pustaka Binama Pressindo.

Saaty, T. L. (2008). Decition making with the analytic hierarchy process. International journal of services sciences, 1(1), pp, 83-98.

Setiawan, F. (2010). Aplikasi Penginderaan Jauh dan GIS untuk Penentuan Lokasi TPA Sampah di Kota Surabaya. Seminar Nasional Alpikasi Teknologi Informasi. Lembaga Ilmu Pengetahuan Indonesia. 19 Juni 2010. Yogyakarta.

SK Menteri Pertanian Nomor 837/Kpts/Um/11/1980 Tentang Kriteria dan Tata Cara Penetapan Hutan Lindung. 1990. Jakarta. 
SK Menteri Pertanian Nomor 683/ Kpts/Um/8/1981 Tentang Kriteria dan Tata Cara Penetapan Hutan Produksi. 1990. Jakarta.

SNI 03-1733-2004 Tentang Tata cara perencanaan lingkungan perumahan di perkotaan.

Undang-Undang Republik Indonesia Nomor 1 Tahun 2011 Tentang Perumahan dan Kawasan Permukiman.
Wirandha, F. S. \& Santosa, P. B. (2018). Analisis Tingkat Kerawanan Kemiskinan di Kota Banda Aceh dengan Metode Analytical Hierachy Process (AHP). Prosiding CGISE ke-4. Yogyakarta 24-25 Oktober 2018. https://repository.ugm.ac.id/276115/ 